\title{
The Impact of Exchange Rate Fluctuations on Foreign Direct Investment in Nigeria
}

\author{
Murtala Zakari \\ Post Graduate School of Accounting and Finance, Leeds Beckett University, Leeds, UK
}

Email address:

murhafs2010@gmail.com, murhab2015@gmail.com

To cite this article:

Murtala Zakari. The Impact of Exchange Rate Fluctuations on Foreign Direct Investment in Nigeria. Journal of Finance and Accounting. Vol. 5, No. 4, 2017, pp. 165-170. doi: 10.11648/j.jfa.20170504.17

Received: May 9, 2017; Accepted: May 22, 2017; Published: July 18, 2017

\begin{abstract}
This study seeks to find out the relationship between foreign exchange rate and foreign direct investment (FDI) and the impact of FDI on the gross domestic product (GDP) in Nigeria, this is important in view of the recent and past devaluation of Nigeria currency as well as the exchange rate changes over the years to be precised 26years coverage (19902015). This underscores the need to assess how foreign investors through FDI respond to changes in the exchange rate, and how this relationship affects GDP with a view to identifying gaps and provide policy recommendations and direction to the policy makers and the Nigeria government. To achieve this, data of FDI, exchange rate, and GDP were obtained from the Central Bank of Nigeria (CBN) website for the period under review and analyzed using regression and correlation analysis techniques. Findings from the analysis show that there is a strong positive relationship between FDI and exchange rate in Nigeria on one hand and there is a weak positive relationship between FDI and GDP on the other hand. The researcher also found that there was a significant inflow of FDI from 2005-2014 due to rise in exchange rate in the same period. The study concludes that exchange rate, FDI, and GDP are positively correlated. The study recommended that Government of Nigeria should fully liberalized exchange rate regime devoid of fixed multiple exchange rates so as to attract more FDI and contribute to GDP, this is because commercial viability of any FDI is based on exchange rate stability.
\end{abstract}

Keywords: FDI, Exchange Rate, GDP, Nigeria

\section{Introduction}

\subsection{Background to the Study}

Foreign direct investment (FDI) is an investment in the form of a controlling ownership in a business enterprise in one country by an entity based in another country. It is thus distinguished from foreign portfolio investment by a notion of direct control. Foreign direct investment includes "mergers and acquisitions, building new facilities, reinvesting profits earned from overseas operations and intra company loans, a lasting management interest (10 percent or more of voting stock) in an enterprise operating in an economy other than that of the investor [12]. Foreign direct investment has grown at a phenomenal rate since the early 1980s, and the world market for it has become more competitive and developing countries are becoming increasingly attractive investment destinations, because they can offer investors a range of "created" assets [16]. According to 2006 World Investment
Report (United Nations) inflows of FDI around the world rose to $\$ 916$ billion, with more than half of these flows received by businesses within developing countries. Foreign Direct Investment (FDI) from developing countries has risen sharply over the past two decades (Lall, 1983; Kumar, 1995; Page 1998; Aykut and Ratha, 2003, and UNCTAD, 2004) cited in [16].

[24] opined that Nigeria's foreign investment can be traced back to the colonial era, when the colonial masters had the intention of exploiting resources for the development of their economy. There was little investment by these colonial masters with the research and discovery of oil, but since then, Nigeria's foreign investment has not been stable. The Nigerian governments have recognized the importance of FDI in enhancing economic growth and development and various strategies involving incentive policies and regulatory measure have been put in place to promote the inflow of FDI to the country. In the same vein, [21] opined that privatization was introduced, among other measures, to 
attract foreign direct investments (FDI) in Nigeria. This involved transfer of state-owned enterprises (manufacturing, agricultural production, public utility services such as telecommunication, transportation, electricity and water supply), companies that are completely or partly owned by or managed by private individuals or companies. [29] noted that since the enthronement of democracy in 1999, the government of Nigeria has taken a number of measures necessary to woo foreign investors into Nigeria. These measures, he noted, include the repeal of laws that are inimical to foreign investment growth, promulgation of investment laws, various oversea trips for image laundry by the country presidents among others.

FDI into Africa increased by 64 percent to $\$ 87 \mathrm{bn}$, while the number of FDI projects declined by 6 percent to 660 in 2014. Coal, Oil \& Natural Gas was the top sector in the region by capital investment accounting for 38 percent of announced FDI. Manufacturing was the top business function in the region by capital investment accounting for 33 percent of announced FDI. FDI into Africa accounted for 13 percent of global FDI in 2014, with the number of projects accounting for 5 percent. Between 2010 and 2014, FDI peaked in 2014 at $\$ 87 \mathrm{bn}$ following the announcement of a multitude of high value projects. In total, 464 companies invested in the region in 2014. Manufacturing, Business Services and Sales, Marketing and Support were the top three business activities of FDI projects into Africa in 2014. In total, 464 companies invested in the region in 2014 compared to 505 in 2013 [22]. One of the many influences on FDI activity is the behaviour of exchange rates. According to [15] exchange rate means how the unit of domestic currency can be change with the other nation's currency unit. They opined that demand and supply of currency actually are the main element of exchange rate instability. Exchange rate instability directly affects the decision makers to decide how much import and export is favorable or otherwise. It also tells that how much things should be manufactured, imported, exported, money taken reserve and balance of payment. Exchange rates can influence both the total amount of foreign direct investment that takes place and the allocation of this investment spending across a range of countries. Khan et al. (2012) cited in [5] opined that exchange rate is the most important factor in an open economy that has a direct effect on the foreign direct investment. Economics, investors and Policy makers focus on the exchange rate of countries and then invest their money in those countries. They believed that increase in exchange rate creates competitive advantages in international trade. By increasing exchange rate of a country the domestic export goods become cheaper and it also increases the demand of export, it means international demand of goods will increase and import will be decreased. It impacts on FDI, all of these effects ultimately on GDP of the country. It is a big opportunity by the volatility of exchange rates for investors, to invest in foreign currency (dollars) to obtain higher yields and leading to strong the dollar against the currency of the home. This directly affects the price of exports and imports [5].
Nigeria is one of the economies with great demand for goods and services and has attracted FDI over the years. The amount of net FDI inflow into Nigeria has reached US\$8.09 billion in 2011 and it has declined down the lines in a row to US\$5.58 billion, US\$4.37 billion, US\$3.08, and US\$1.63 in 2012, 2013, 2014, and 2015 respectively. In 2015 the net inflow after deducting the outflow was worst hit which stood at US\$1.63 representing $47 \%$ decline compare to 2014 and $80 \%$ decline in a row from 2011 [20].

The question that comes to mind is, do these FDIs actually affected by exchange rate fluctuations in Nigeria? Do the FDIs contribute to gross domestic product (GDP) in Nigeria? If FDIs are actually affected by exchange rate and impacted on the GDP, then the sustainability of FDIs is a worthwhile activity and the way to achieve this is by researching the variables responsible for these impacts with a view to ensuring its development and improvement. However, most studies and debates on FDI, exchange rate and economic growth are country specific [16]. Previous studies in Nigeria by $[25,26,3,16]$ examined only the importance of FDI on economic growth and the channels through which it may be benefiting the economy.

This study aims to examine the impact of exchange rate on FDI and the contributions of FDI to GDP in Nigeria.

\subsection{Hypotheses}

1. There is a positive relationship between FDI and exchange rate

2. There is a positive relationship between FDI and GDP

\section{Literature Review}

Foreign Direct Investment (FDI) is an international flow of capital that provides a parent company or multinational organization with control over foreign affiliates [9]. Foreign direct investment is investment of foreign assets into domestic structures, equipment, and organizations. It does not include foreign investment into the stock markets. Foreign direct investment is thought to be more useful to a country than investments in the equity of its companies because equity investments are potentially "hot money" which can leave at the first sign of trouble, whereas FDI is durable and generally useful whether things go well or badly [5]. In the same vein, [13] opined that the role of Foreign Direct Investments for growth in developing countries is very important. Foreign investors are motivated to invest in the host country, if the prospect of making long-term profits by contributing area that host country of production are very obvious. The foreign direct investment not only plays its vital role to capital formation in developing countries, but it is a source of technology transfer and innovative skills from developed to developing countries. For the development of the least developed countries, these countries offer incentives to foreign investors in order to attract more Foreign Direct Investments. According to [23], foreign direct investment (FDI) is different from other private capital inflows such as portfolio investment since, in addition to equity-based 
ownership, direct foreign investment implies a direct or lasting interest in, and control of, an enterprise. FDI also depends on the political system of the country. The trade policy can encourage FDI to capture the domestic market and facilitate national population; in countries following research inward [11].

Exchange rate means how the unit of domestic currency can be change with the other nations' currency unit. Simply it is change of one country currency into the other country currency. The demand and supply of currency actually are the main element of exchange rate instability. Exchange rate instability directly affects the decision makers to decide that how much import and export is favourably [15]. It also tells that how much things should be manufactured, import, export, money taken reserve and balance of payment. Exchange rate also impacts on the prices of export, import and balance of payment. Exchange rate works as a great opportunity for domestic investor to earn high profit by investing in foreign currency. The investors and traders like that system where there is very small inconsistency difference, between actual and expected value of exchange rate. The instability in exchange rate is source of higher profit; it is the perception of one school of thought [15]. In the same vein, [10] opined that changes in the exchange rate have two opposite effects on investment. When the domestic currency depreciates, the marginal profit of investing an additional unit of capital is likely to increase, because there are higher revenues from both domestic and foreign sales. Yet, this positive effect is counterbalanced by the rising variable cost and the higher price for imported capital. Theoretical models provide no clear indication as to which effect is dominant. The overall effect of exchange rates on investment remains an empirical question [10]. Currency value can be explained two ways. The First one is when the currency is devaluated, the domestic goods become cheaper and the foreign goods becomes expensive the demand of local products increases, and then the foreign country definitely improves trade balance and promotes local goods. The second one is real value of cash reduce due to devaluation of money. The foreign currency export become cheaper and import become expensive when the value of local currency and goods goes down [5].

A popular claim in the international business community is that exchange rates are one of the most important factors in a firm's foreign direct investment decision, because a devaluation of a country currency can give foreigners an edge in buying the country's asset [9]. Given the inadequacy of the traditional theories, a lot of work recently has been done in the area of exchange rate movement and FDI, but there is still no consensus either in theory or empirical studies [6]. In the same vein, [9] opined that the depreciation of the destination market currency raises the relative wealth of source country agents and can raise multinational acquisitions of certain destination market assets. To the extent that source country agents hold more of their wealth in own currency-denominated form, a depreciation of the destination currency increases the relative wealth position of source country investors, lowering their relative cost of capital. This allows the investors to bid more aggressively for assets abroad. Empirical support for this channel is provided by [18] who shows that the importance of this relative wealth channel exceeded the importance of the relative wage channel in explaining FDI inflows to the United States during the period from 1979 through 1991. [19] and [7] showed that foreign currency depreciation lowers the foreign production cost and this stimulates FDI. [8] developed a model with an imperfect market and show that a depreciation of the domestic currency, by systematically lowering the relative wealth of domestic agents, can lead to foreign acquisition.

It is worthy of note that a number of theoretical models have emerged in the literature regarding the volatility of exchange rates. These models give the direction how the volatility in exchange rates affects the trade flows positively or negatively, it depends upon various factors, including assumptions about risk attitudes. The most common explanations are the transaction cost, for the negative relationship between exchange rate volatility and trade flows. The cost of converting a currency to other and the risk associated with potential changes in exchange rates have a dampening effect on trade flows. Lot of theories has analysed the impact response of commercial enterprises to exchange rate uncertainty, by focusing on their degree of risk aversion. [14] and [10] opined that if domestic firms rely heavily on imported inputs in production, exchange rate depreciation can have a negative impact on their investment decision: an increase in the variable cost of production and the user cost of capital reduces the marginal profit of investment. Moreover, their theoretical framework shows that investment in industries with weaker market power is more likely to be affected by exchange rate movements. A reasonable explanation is that firms with stronger monopoly power have a greater ability to adjust their cost-price margin without altering their production and investment decisions, whereas adjustments in the low mark-up industries are largely reflected in their profits. The following theoretical frame work shows the relationship between exchange rate which is independent variable and foreign direct investment as the dependent variable

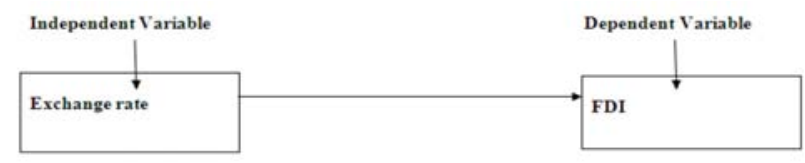

Figure 1. Theoretical Frame of the Study.

Previous studies on the Foreign Direct Investment (FDI) and economic growth in Nigeria and other countries provided inconclusive results as follows;

[5] found the relationship between Exchange rate and FDI in Pakistan. In correlation there is positive significant relationship between Exchange rate and FDI. The reason is that Pakistan is a developing country with rich natural resources and low labour cost, when the foreign company wants to invest in local currency of Pakistan, the company 
sees the currency exchange rate of Pakistan and when the exchange rate of Pakistan currency is high; simply it means that the company receives more currency for investment in Pakistan. So it has been proved in their research that exchange rate positively impacts on the Foreign Direct Investment. [1] studied the impact of foreign direct investment on Nigeria's economic growth over the period of 1999-2013. The findings revealed that economic growth is directly related to inflow of foreign direct investment and statistically significant at 5\% level. This implies that a good performance of the economy is a positive signal for inflow of foreign direct investment. [30] investigated the empirical relationship between Foreign Direct Investment and economic growth in Nigeria. The work covered a period of 1981-2009 using an annual data from Central Bank of Nigeria statistical bulletin. A growth model via the Ordinary Least Square method was used to ascertain the relationship between FDI and economic growth in Nigeria. The result of the OLS techniques indicated that FDI has a positive but has insignificant impact on Nigerian economic growth for the period under study. [27] found that uncertainty of exchange rates may have a positive impact on imports and exports and negative for trader's lover risk and vice versa for risk averter traders. [28] found that the benefits of exchange rate depreciation in Pakistani rupee are decreasing up to 30 years as compare to foreign currency. The floating exchange rates depend upon market situation. It's done with the hope of balance of trade. [17] found that there is the existence of a strong negative and significant impact on the volatility of the real exchange rate on investment at the plant in Colombia. [4] found that there is the existence of the negative and significant relationship of the volatility of exchange rates on FDI in member countries of the EU to Central and Eastern Europe.

\section{Research Methodology}

This research is based on secondary data and time series. Data were collected from the website of Central Bank of Nigeria. The variables of this study are Foreign Direct Investments (FDIs), Exchange Rate, and Gross Domestic Product (GDP). The study is long term analysis. First, to check the impact of exchange rate on FDI in Nigeria using 26 years data of exchange rates and FDIs for the period (1990 to 2015). Second, to check the relationship between FDI and Gross Domestic Product (GDP) in Nigeria. The researcher used the test of Correlation and regression in SPSS software to check the relationship between the variables. This study will be descriptive because substantial year data is at hand and how the exchange rate impacts FDI on one hand, and how the FDI affects GDP on the other hand in the past. The type of investigation is co-relational study because the researcher is interested in outlining the important variables associated with the problem. Hence, the researcher gave detailed description of all the results and findings from the study. This method was adopted by previous researchers (Bilawal, M., Ibrahim, M., Abbas, A., Shuaib, M., Ahmed,
M., Hussain, I., Fatima, 2014).

\section{Data Analysis and Discussion}

\subsection{Correlation Analysis}

Correlation analysis shows the relationship among different variables. The correlation ranges from -1 to +1 . The significant relationship among different variables lies from 0.01 to 0.05 . The significance value more than 0.05 shows the insignificant relationship among the variables. The Mathematical signs like + , - show the direction of relation. The +1 value shows the perfect Positive relation and -1 value shows the perfect negative relationship. The zero value shows that there is no any relationship among the variables.

Table 1. Correlation.

\begin{tabular}{lll}
\hline & GDP (N'm) & Fx (N'm) \\
\hline $\mathrm{R}^{2}$ & 0.229 & 0.551 \\
$\mathrm{R}$ & 0.479 & 0.742 \\
Relationship & $+\mathrm{ve}$ & $+\mathrm{ve}$ \\
\hline
\end{tabular}

Source: SPSS output of FX, FDI, and GDP data (1990-2015) obtained from CBN websites.

The above result in Table1 shows that there is a strong positive relationship between foreign direct investment and foreign exchange rate in Nigeria with correlation coefficient $\mathrm{r}(0.742)$. Furthermore, there is a weak positive relationship between foreign direct investment and gross domestic product in Nigeria with correlation coefficient $\mathrm{r}(0.479)$

\subsection{Multiple Regression Analysis}

Regression analysis is used to show the accuracy and appropriateness of model and how much independent variable influence on the dependent variable in this study.

Table 2. Model Summary.

\begin{tabular}{|c|c|c|c|c|}
\hline \multicolumn{5}{|c|}{ Dependent variable: FDI ( 'm) } \\
\hline Parameter & Estimate & $\begin{array}{l}\text { Standard } \\
\text { Error }\end{array}$ & T Statistic & P-Value \\
\hline CONSTANT & -77213.683 & 100764.023 & -0.766 & 0.451 \\
\hline GDP (N'm) & 0.009 & 0.478 & 0.018 & 0.986 \\
\hline Fx (N'm) & 4619.960 & 11.39967 & 4.053 & 0.000 \\
\hline \multicolumn{5}{|c|}{$\begin{array}{l}\text { R-squared }=55.1 \text { percent } \\
\text { R-squared (adjusted for d.f.) }=51.2 \text { percent } \\
\text { Standard Error of Est. }=266380.8\end{array}$} \\
\hline
\end{tabular}

Source: SPSS output of FX, FDI, and GDP data (1990-2015) obtained from CBN websites.

The output in Table 2 shows the results of fitting a multiple linear regression model to describe the relationship between Foreign Direct Investment and 2 independent variables. The equation of the fitted model is FDI ( $\mathrm{m})=-$ $7721.683+0.009 *$ GDP (N'm) + 4619.960* Fx (N'm).

Since the P-value in the ANOVA table is less than 0.01, there is a statistically significant relationship between the variables at the $99 \%$ confidence level, this connotes that the above model is statistically significant. The R-Squared 
statistic indicates that the model as fitted explains $55.1 \%$ of the variability in Foreign Direct Investment in Nigeria. The adjusted R-squared statistic, which is more suitable for comparing models with different numbers of independent variables, is $51.2 \%$. The standard error of the estimate shows the standard deviation of the residuals to be 266380.8 . In determining whether the model can be simplified, notice that the highest P-value on the independent variables is 0.986 , belonging to Gross Domestic product. Since the P-value is greater or equal to 0.10 , that term is not statistically significant at the $90 \%$ or higher confidence level. Consequently, this implies that Gross Domestic Product does not have influence on Foreign Direct Investment in Nigeria. Thus the model revealed that an increase in foreign exchange rate is accompanied by an increase of $\$ 4619.960$ million in foreign direct investment in Nigeria.

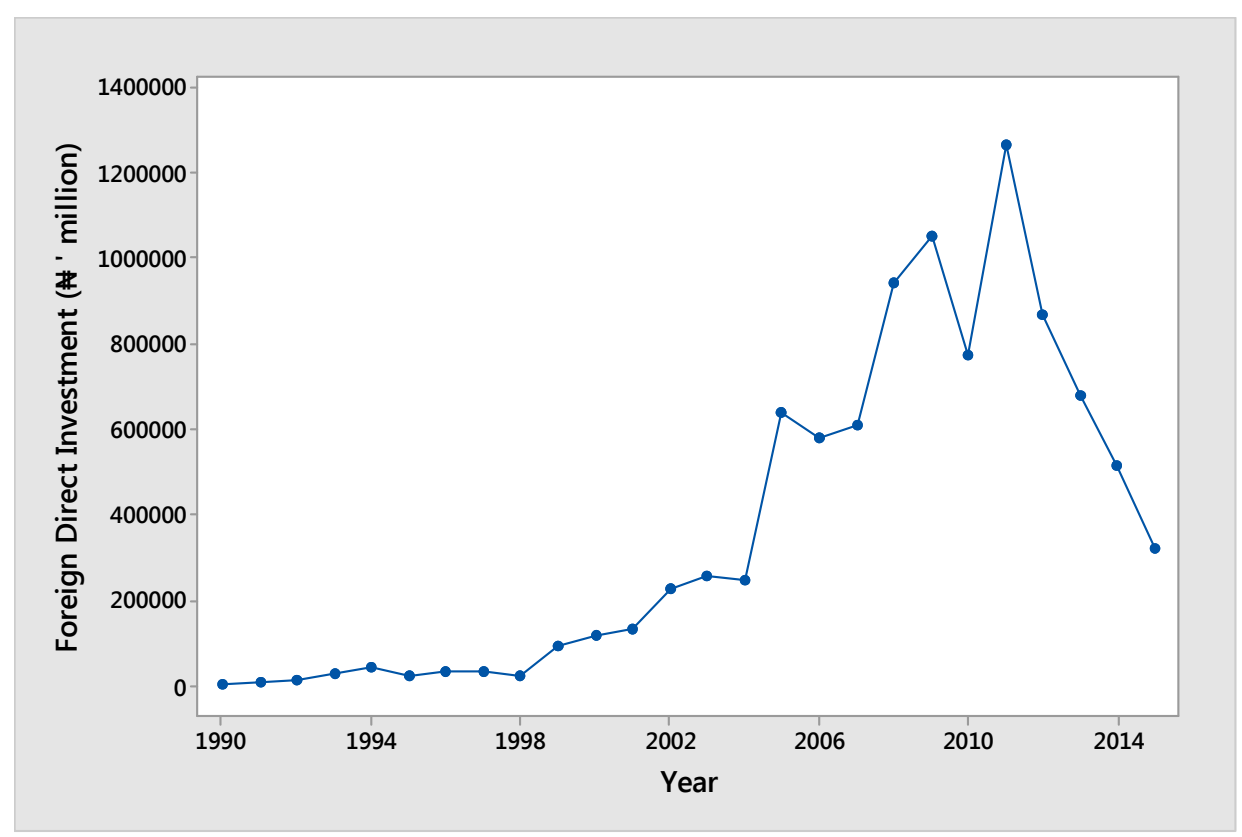

Figure 2. Time series analysis of Federal Direct Investment.

The above figure explains the time series analysis of federal direct investment (N'millions) in Nigeria from year 1990-2015, thus it indicates that there was a high level of foreign direct investment (FDI) from 2005-2014.

The empirical finding of this study is consistent with the empirical result of [5], which found that there is positive significant relationship between exchange rate and FDI. The finding is also consistent with other previous studies $[1,30]$. However, there are similar studies [4, 17] whose empirical results negate the finding of this study. [4, 17] found that there is existence of negative and significant relationship of the volatility of exchange rates on FDI.

\section{Conclusion}

The finding of this study shows that there is a strong positive relationship between FDI and exchange rate in Nigeria. This satisfied the first hypothesis of this research, i.e. "There is a positive relationship between FDI and exchange rate". Furthermore, this research found that there is a weak positive relationship between foreign direct investment and gross domestic product in Nigeria. This satisfied the first hypothesis of this research, i.e. "There is a positive relationship between FDI and GDP". The study concludes that exchange rate, FDI, and GDP are positively correlated.

\section{Policy Recommendations}

1. Government of Nigeria should fully liberalized exchange rate regime devoid of multiple exchange rates so as to attract more FDI and saving the existing and prospective foreign direct investors from exposure to loss. Commercial viability of any FDI is based on exchange rate stability.

2. Government of Nigeria should ensure stability in governance, policies, and legislations. A stable Government is an essential prerequisite for any investment. Investors should not have any fear of takeover by the government or introducing policies/steps that are anti-investment. Consistency in government policies, legislations, and governance will attract more FDI and prevent capital flight.

3. Government should create an enabling environment for businesses to thrive. The infrastructure decay in the country is discouraging FDI inflow and invariably impacting the GDP. Government should undertake pro-active measures such as expansion and standardization of air ports, sea ports, stable power, development of highways, improved security, etc. These measures will attract more foreign direct investment 


\section{References}

[1] Adeleke, K. M., Olowe, S. O., Fasesin, O. O., (2014) "Impact of Foreign Direct Investment on Nigeria Economic Growth": International Journal of Academic Research in Business and Social Sciences, Vol. 4, No. 8

[2] Africa Investment Report (2015): FDI Intelligence, Global Insight Financial Times Ltd.

[3] Akinlo, A. E. (2004): "Foreign direct investment and growth in Nigeria: An Empirical Investigation".Journal of Policy Modelling, 26, pp. 627-39.

[4] Arratibel, O., Furceri, D., Martin, R., and Zdzienicka, A. (2011). "The Effect of Nominal Exchange Rate Volatility on Real Macro Economic Performance in the CEE Countries". Economic Systems, 35.

[5] Bilawal, M., Ibrahim, M., Abbas, A., Shuaib, M., Ahmed, M., Hussain, I., Fatima, T., (2014) "Impact of Exchange Rate on Foreign Direct Investment in Pakistan": Journal of Advances in Economics and Business 2 (6): 223-231.

[6] Chen, K. M., Rau, H. H. and Lin, C. C. (2005) "The Impact of Exchange Rate Movements on Foreign Direct Investment: Market-Oriented Versus Cost-Oriented. In Economic Integration and Economic Development. Proceedings of an International Conference @ Xi'an Jiaotong University, Xi'an China.

[7] Cushman, D. (1985). "Real exchange Rate Risk, Expectations and the level of Direct Investment", the Review of Economics and Statistics, 67, 297-308.

[8] Froot, K., and Stein, J. (1991) "Exchange Rates and Foreign Direct Investment: An Imperfect Capital Markets Approach", Quarterly Journal of Economics 1191-1217.

[9] Goldberg, L. and Charles, K. (2005) "Foreign Direct Investment, Exchange Rate Variability and Demand Uncertainty." International Economic Review, vol. 36 no. 4, pp.855-73.

[10] Harchaoui, T., Tarkhani, F. and Yuen, T. (2005) "The Effects of the Exchange Rate on Investment: Evidence from Canadian Manufacturing Industries", Working Paper 2005-22 / Document de travail 2005-22, Bank of Canada Banque du Canada.

[11] Hassan, M. and Mahmood, H. (2013). “An Empirical 230 Impact of Exchange Rate on Foreign Direct Investment in Pakistan".

[12] Https://en.wikipedia.org.

[13] Huchet-Bourdon, M. and Korinek, J. (2011). To What Extent Do Exchange Rates and their Volatility Affect Trade? OECD trade policy, 119.

[14] Ibrahim, M., Muhammad K. S., Sayed F. A. (2014). "The Impact of Telecom Services Characteristics on Consumer for Use in Pakistan". Advances in Economics and Business 2(4): 172-179.

[15] Javed, Z. \& Farooq, M. (2009). "Economic growth and exchange rate volatility in Case of Pakistan". Pakistan journal of life and social sciences, 2, 112-118.

[16] Kabir, H. D, (2012)," Foreign Direct Investment and the Nigerian Economy": American Journal of Economics, 2 (3): 33-40.

[17] Kandilov, T. I. and Leblebiciogles, A. (2011). "The Impact of Exchange Rate Volatility on Plant-level Investment": Evidence from Colombia's Journal of Development Economics, 94, 220-230.

[18] Klein, M. and E. Rosengren, (1994) "The Real Exchange Rate and Foreign Direct Investment in the United States: Relative Wealth vs. Relative Wage Effects," Journal of International Economics vol.36.

[19] Kohlhagen, S. W (1977) "Exchange Rate Changes, Profitability and Direct Foreign Investment" Southern Economic Journal, 44, 376-386.

[20] Knoema.com/UNCTADFDIF2016/foreign-direct-investmentflow-2015.

[21] Lall (2002): "Foreign Investment Transactional and Development Countries", MacmillanPress Ltd, London.

[22] LOCOmonitor.com.

[23] Loungani, P. and Razin, A. (2001). "How beneficial is Foreign Direct Investment for Developing Countries? Finance \& Development, 38 (2), 6-9.

[24] Macaulay, E. D (2012). "Foreign Direct Investment and the Performance of the Nigerian Economy. Proceedings of the 1st International Technology, Education and Environment Conference.Pp $629-633$

[25] Otepola, A. (2002) "Foreign Direct Investment as a factor of Economic Growth in Nigeria." Africa Institute for Economic Development and Planning (IDEP), Dakar, Senegal.

[26] Oyejide, T. A. (2005) Capital Flows and Economic Transformation: A Conceptual Framework on Proceedings of Central Bank of Nigeria 5th Annual Monetary Policy Conference with the theme "Capital Flows and Economic Transformation in Nigeria." Held at the CBN Conference Hall, Abuja. November 10th to 11th.

[27] Payaslioglu, C. \& Polit, B. (2013) "Impact of exchange rate uncertainty on FDI inward into Turkey". WEI international academic conference proceeding.

[28] Rehman, A. Adil, I. \& Anis, H. (2012). "Exchange rate, j curve and debt burden of Pakistan" Pakistan economic and social review, 50, 41-56.

[29] Shiro, A. A. (2009) "The Impact of FDI on the Nigerian Economy". Paper delivered at the 2nd National Conference organised by the Department of Finance, university of Lagos, Lagos State. Retrieved from: www.unilag.edu.ng/researchview.

[30] Solomon, H. C and Eka, O. O (2013). "Impact of Foreign Direct Investment on Telecommunication Sector on Nigerian Economy". International Journal of Modern Social Sciences. 2 (3): 195-215. 